\title{
TENDÊNCIAS DO CONTROLE PENAL NA ÉPOCA CONTEMPORÂNEA reformas penais no Brasil e na Argentina
}

Rodrigo Ghiringhelli de Azevedo

\begin{abstract}
Resumo: Este artigo parte da análise comparativa das reformas da legislação penal no Brasil e na Argentina, identificando três âmbitos de mudança: a expansão do Direito Penal, o Processo Penal de Emergência e a informalização da Justiça Penal. O estudo realizado visa contribuir para a compreensão dos movimentos de política criminal que se expressam através das reformas legais investigadas.

Palavras-chave: reformas penais; política criminal; informalização da justiça.

Abstract: This article begins with a comparative analysis of the reforms in penal legislation in Brazil and Argentina, identifying three areas of change: the expansion of Penal Law, the Emergency Penal Process, and the informalization of Penal Justice. The study attempts to contribute to the understanding of the criminal policy movements behind the legal reforms being examined.

Key words: penal reforms; criminal policy; informalization of justice.
\end{abstract}

$\mathrm{E}$

ntre o conjunto de reformas no funcionamento da máquina estatal, realizadas nos países da América Latina a partir do final dos anos 80 , e que tiveram por objetivo tanto a reconstituição e modernização de uma institucionalidade democrática quanto a adequação ao chamado "Consenso de Washington", no sentido de uma redução da atividade estatal às tarefas essenciais de promoção do crescimento econômico e manutenção da ordem, uma das áreas em que tais mudanças vêm ocorrendo, de forma pontual, fragmentada e muitas vezes contraditória, é a que diz respeito ao poder de punir do Estado: a administração do controle penal, desde a tipificação de novos delitos até o funcionamento dos órgãos policiais, passando pelos procedimentos dos órgãos oficiais de administração da justiça e o sistema prisional.

Com a redemocratização, os novos administradores do Estado, agora eleitos pelo voto popular, depararam-se com uma situação de aumento das taxas de criminalidade, decorrente de fatores como a grande concentração populacional produzida pela migração do campo para as grandes metrópoles urbanas, consolidada no Brasil durante o período de governo militar que, por meio do arbítrio, re- presou muitos bolsões de conflitualidade social emergente (Adorno, 1994).

Para os novos governos eleitos na região, em todas as esferas de administração (federal, estadual e municipal), o problema da segurança pública tem sido colocado como uma das principais demandas da chamada "opinião pública", muitas vezes amplificada por via da atuação dos meios de comunicação de massa. O "sentimento de insegurança" é crescente, com o aumento da percepção pública a respeito das diversas esferas da criminalidade, desde a economia do tráfico na favela e a criminalidade urbana violenta até os centros dos sistemas político e financeiro, onde ocorre a lavagem de dinheiro e o desvio de recursos públicos para o enriquecimento privado. A resposta estatal é insistentemente cobrada, e colocada no centro do debate político em períodos eleitorais.

O resultado é a crescente perda de legitimidade do sistema penal, incapaz de justificar o seu grau de seletividade e a sua incapacidade de dar resposta ao sentimento de insegurança e impunidade da maioria da população (Zaffaroni, 1991). O sistema político reage com propostas de reforma do sistema de controle penal. 
Em relação à polícia, o debate gira em torno da sua reciclagem, para atuar em um Estado Democrático de Direito, visando assegurar os direitos de cidadania de toda a população, e não apenas das elites; também com vistas à economia administrativa e à racionalização dos esforços de informação e prevenção necessários ao enfrentamento da criminalidade em seus vários níveis, com a redução da seletividade na atividade policial, ou o seu redirecionamento para os delitos mais graves em termos de conseqüências sociais. Tais mudanças esbarram em uma cultura repressiva, fruto do papel historicamente desempenhado pela polícia em países com grande desigualdade social, como Brasil e Argentina.

O sistema judicial é alvo de constantes propostas de mudança, que ocorrem de forma fragmentada, por meio de leis muitas vezes feitas ao sabor dos clamores da opinião pública, amplificados pela mídia, sem uma unidade capaz de garantir um mínimo de segurança jurídica e coerência interna (Koerner, 2000). Novos delitos são criados, novas áreas de criminalização aparecem, novos procedimentos são propostos, tudo na tentativa de recuperar a legitimidade perdida e um mínimo de eficácia frente a uma realidade social que cada vez mais foge ao controle dos mecanismos institucionais de controle penal.

O sistema prisional, carente de meios para responder ao número crescente de condenados que lhe é enviado, tradicionalmente degradante e estigmatizante em todo o continente, carece de toda a possibilidade de ressocialização, servindo mais como ponto de reunião de toda uma cultura da delinqüência, cujos maiores beneficiários dificilmente recebem uma pena privativa de liberdade (Velho e Alvito, 1996:290-304).

Além da dimensão local e conjuntural do problema da segurança pública, a reforma do sistema de controle penal precisa também ser compreendida na sua relação com determinados fenômenos mais abrangentes, que têm sido objeto da sociologia jurídica, como a judicialização crescente da realidade social e a pluralidade de formas e de graus de incidência das normas sobre o espaço social, levando à necessidade daquilo que Boaventura Sousa Santos denomina uma cartografia simbólica do direito na transição pós-moderna (Santos, 1996:260).

Essa cartografia pressupõe que, ao contrário da tradição jurídica dogmática, circulam na sociedade não uma, mas várias formas de direito ou modos de juridicidade e, na área penal, a conseqüência disso é que a eficácia da legislação penal depende de uma série de mediações com os mecanismos institucionais e burocráticos responsáveis pela sua aplicação na realidade social em que atuam.

\section{REFORMAS PENAIS NA ÚLTIMA DÉCADA}

\section{Expansão do Direito Penal}

Uma das tendências mais evidentes no tocante às normas penais nas sociedades contemporâneas é a da hipertrofia ou inflação de normas penais, que invadem campos da vida social anteriormente não regulados por sanções penais. O remédio penal é utilizado pelas instâncias de poder político como resposta para quase todos os tipos de conflitos e problemas sociais.

A resposta penal converte-se em resposta simbólica (Baratta, 1994) oferecida pelo Estado em face das demandas de segurança e penalização da sociedade, expressadas pela mídia, sem relação direta com a verificação de sua eficácia instrumental como meio de prevenção ao delito. O direito penal converte-se em recurso público de gestão de condutas utilizado contingencialmente, e não mais como instrumento subsidiário de proteção de interesses ou bens jurídicos. Nos casos de Brasil e Argentina, a inclusão de algumas novas áreas dentro do denominado controle penal formal não foi compensada pela diminuição do rigor repressivo nas áreas tradicionalmente submetidas ao controle penal convencional.

Entre as áreas novas ou ao menos distintas das tradicionalmente contidas no Código Penal brasileiro e no argentino, atingidas pela expansão do direito penal, cabe mencionar as disposições penais em matéria de delitos econômicos e financeiros - sonegação fiscal, lavagem de dinheiro, etc. (Brasil e Argentina); criminalização das condutas contrárias às relações de consumo (Brasil); criminalização de delitos ambientais (Brasil) e relacionados com resíduos perigosos (Argentina); tipificação de delitos de discriminação racial ou de outro tipo e da chamada criminalidade organizada (Brasil e Argentina); criminalização do assédio sexual (Brasil) e de condutas relacionadas com espetáculos esportivos e terrorismo (Argentina).

\section{Processo Penal de Emergência}

Para caracterizar esse momento de mudanças no âmbito da legislação e das práticas punitivas, têm sido utilizada a denominação direito penal de emergência, ou processo penal de emergência (Ferrajoli, 2002). Conforme Fauzi Choukr (2002:6), "Emergência vai significar aquilo que foge dos padrões tradicionais de tratamento pelo sistema repressivo, constituindo um subsistema de derrogação dos cânones culturais empregados na normalidade. Num certo sentido, a criminologia contemporânea 
dá guarida a esse subsistema, colocando-o na escala mais elevada de gravidade criminosa a justificar a adoção de mecanismos excepcionais a combatê-la, embora sempre defenda o modelo de estado democrático de direito como limite máximo da atividade legiferante nessa seara".

No Brasil, a emergência penal pode ser constatada com a edição da Lei $n^{\circ}$ 8.072/90, conhecida como Lei dos Crimes Hediondos, que regulamentou o que havia sido previsto na Constituição de 1988, que no art. 5º inciso XLIII, criou a figura dos crimes hediondos, nos seguintes termos:

"XLIII - A lei considerará crimes inafiançáveis e insuscetíveis de graça ou anistia a prática de tortura, o tráfico ilícito de entorpecentes e drogas afins, o terrorismo e os definidos como crimes hediondos, por eles respondendo os mandantes, os executores e os que, podendo evitálos, se omitirem; (...)."

Em seu art. $1^{\circ}$, a Lei $n^{\circ} 8.072 / 90$ definiu como hediondos os delitos de homicídio qualificado e homicídio praticado em atividade típica de grupo de extermínio, o latrocínio, a extorsão qualificada pela morte, a extorsão mediante seqüestro e na forma qualificada, o estupro e o atentado violento ao pudor, a epidemia com resultado morte, falsificação, corrupção, adulteração ou alteração de produto destinado a fins terapêuticos ou medicinais, consumados ou tentados. O parágrafo único do art. $1^{\circ} \mathrm{da}$ mesma lei rotulou também como hediondo o crime de genocídio previsto nos arts. $1^{\circ}, 2^{\circ}$ e $3^{\circ}$ da Lei $n^{\circ} 2.889$, de $1^{\circ}$ de outubro de 1956 , tentado ou consumado, com redação dada pela Lei $n^{\circ} 8.930 / 94$.

Em seus arts. $2^{\circ}$ e $3^{\circ}$, a Lei ${ }^{\circ} 8.072 / 90$ estabeleceu as regras aplicáveis aos delitos hediondos e aos a eles equiparados, nos seguintes termos:

“Art. $2^{\circ}$ - Os crimes hediondos, a prática da tortura, o tráfico ilícito de entorpecentes e drogas afins e o terrorismo são insuscetíveis de:

I - anistia, graça e indulto;

II - fiança e liberdade provisória.

$\S 1^{\circ}$ - A pena por crime previsto neste artigo será cumprida integralmente em regime fechado.

$\S 2^{\circ}$ - Em caso de sentença condenatória, o juiz decidirá fundamentadamente se o réu poderá apelar em liberdade.

$\S 3^{\circ}$ - A prisão temporária, sobre a qual dispõe a Lei $\mathrm{n}^{\circ}$ 7.960, de 21 de dezembro de 1989, nos crimes previstos neste artigo, terá o prazo de 30 (trinta) dias, prorrogável por igual período em caso de extrema e comprovada necessidade.

Art. $3^{\circ}$ - A União manterá estabelecimentos penais, de segurança máxima, destinados ao cumprimento de penas impostas a condenados de alta periculosidade, cuja per- manência em presídios estaduais ponha em risco a ordem ou incolumidade pública."

$\mathrm{O}$ art. $5^{\circ}$ acrescentou inciso ao art. 83 do Código Penal, determinando que, para que haja a concessão de livramento condicional ao condenado a pena privativa de liberdade, nos casos de condenação por crime hediondo, prática de tortura, tráfico ilícito de entorpecentes e drogas afins, e terrorismo, deverão ter sido cumpridos mais de dois terços da pena.

$\mathrm{O}$ art. $6^{\circ}$ da Lei dos Crimes Hediondos aumentou a pena dos delitos rotulados como hediondos. Para exemplificar, o latrocínio, que tinha pena mínima de quinze anos de reclusão, passou ao mínimo de vinte anos; a extorsão mediante seqüestro, cuja pena mínima era de seis anos de reclusão, passou a ter o mínimo no patamar de oito anos. O mesmo crime, se praticado contra menor de dezoito anos ou por quadrilha, ou se durar mais de 24 horas, que tinha pena mínima de oito anos, passou para doze anos de reclusão. Se do seqüestro resultar a morte, a pena mínima, que era de vinte anos, passou para 24 anos. O estupro, que tinha pena mínima de três anos de reclusão e oito como máxima, passou ao mínimo de seis anos e máximo de dez anos. O atentado violento ao pudor passou de um apenamento mínimo de dois anos e máximo de sete anos para seis e dez anos, respectivamente.

O mesmo diploma legal introduziu pela primeira vez no ordenamento jurídico brasileiro a figura da delação premiada, prevendo que o participante e o associado que denunciarem à autoridade o bando ou quadrilha, possibilitando seu desmantelamento, terão a pena reduzida de um terço a dois terços.

Outro exemplo de legislação emergencial é a Lei $n^{\circ}$ 9.034/95, que dispõe sobre a utilização de meios operacionais (meios de prova e procedimentos investigatórios) para a prevenção e repressão de ações praticadas por organizações criminosas. $\mathrm{O}$ art. $1^{\circ}$ define organizações criminosas como sinônimo de quadrilha ou bando ou organizações ou associações criminosas de qualquer tipo. De acordo com o art. $2^{\circ}$, em qualquer fase de persecução criminal são permitidos, sem prejuízo dos já previstos em lei, os seguintes procedimentos de investigação e formação de provas:

"II - a ação controlada, que consiste em retardar a interdição policial do que se supõe ação praticada por organizações criminosas ou a ela vinculado, desde que mantida sob observação e acompanhamento para que a medida legal se concretize no momento mais eficaz do ponto de vista da formação de provas e fornecimento de informações; 
III - o acesso a dados, documentos e informações fiscais, bancárias, financeiras e eleitorais;

IV - a captação e a interceptação ambiental de sinais eletromagnéticos, óticos ou acústicos, e o seu registro e análise, mediante circunstanciada autorização judicial;

$\mathrm{V}$ - infiltração por agentes de polícia ou de inteligência, em tarefas de investigação, constituída pelos órgãos especializados pertinentes, mediante circunstanciada autorização judicial.

Parágrafo único. A autorização judicial será estritamente sigilosa e permanecerá nesta condição enquanto perdurar a infiltração."

$\mathrm{O}$ art. $3^{\circ}$ prevê que, nas hipóteses do inciso III do art. $2^{\circ}$, ocorrendo possibilidade de violação de sigilo preservado pela Constituição ou por lei, a diligência será realizada pessoalmente pelo juiz, adotado o mais rigoroso segredo de justiça. Para realizar a diligência, o juiz poderá requisitar o auxílio de pessoas que, pela natureza da função ou profissão, tenham ou possam ter acesso aos objetos de sigilo. O juiz, pessoalmente, fará lavrar auto circunstanciado da diligência, relatando as informações colhidas oralmente e anexando cópias autênticas dos documentos que tiverem relevância probatória, podendo, para esse efeito, designar uma das pessoas referidas no parágrafo anterior como escrivão ad hoc. O auto de diligência será conservado fora dos autos do processo, em lugar seguro, sem intervenção de cartório ou servidor, somente podendo a ele ter acesso, na presença do juiz, as partes legítimas na causa, que não poderão dele servir-se para fins estranhos à mesma, e estão sujeitas às sanções previstas pelo Código Penal em caso de divulgação.

Conforme o $\S 4^{\circ}$ do art. $3^{\circ}$, os argumentos de acusação e defesa que versarem sobre a diligência serão apresentados em separado para serem anexados ao auto da diligência, que poderá servir como elemento na formação da convicção final do juiz. E o $\S 5^{\circ}$ estabelece que, em caso de recurso, o auto da diligência será fechado, lacrado e endereçado em separado ao juízo competente para revisão, que dele tomará conhecimento sem intervenção das secretarias e gabinetes, devendo o relator dar vistas ao Ministério Público e ao Defensor em recinto isolado, para o efeito de que a discussão e o julgamento sejam mantidos em absoluto segredo de justiça.

O capítulo III do referido diploma legal estabelece, em seu art. $4^{\circ}$, que os órgãos da polícia judiciária estruturarão setores e equipes de policiais especializados no combate à ação praticada por organizações criminosas, sendo que a identificação criminal de pessoas envolvidas com a ação praticada por organizações criminosas será realizada independentemente da identificação civil (art. $5^{\circ}$ ).

Uma das principais inovações previstas pela Lei ${ }^{\circ}$ 9.034/95, em seu art. $6^{\circ}$, era que, nos crimes praticados em organização criminosa, a pena será reduzida de um a dois terços, quando a colaboração espontânea do agente levar ao esclarecimento de infrações penais e sua autoria.

$\mathrm{O}$ art. $7^{\circ}$ impede a concessão de liberdade provisória, com ou sem fiança, aos agentes que tenham tido intensa e efetiva participação na organização criminosa, estabelecendo o art. $8^{\circ}$ que o prazo para encerramento da instrução criminal, nos processos por crime de que trata esta lei, será de 81 dias, quando o réu estiver preso, e de 120 dias, quando solto.

Dispõe ainda o art. $9^{\circ}$ que o réu não poderá apelar em liberdade, nos crimes previstos nesta Lei. O art. 10 estabelece que os condenados por crimes decorrentes de organização criminosa iniciarão o cumprimento da pena em regime fechado, aplicando-se, no que não forem incompatíveis, subsidiariamente, as disposições do Código de Processo Penal.

Na Argentina, exemplos de legislação emergencial também podem ser encontrados, no âmbito do controle penal do tráfico de entorpecentes. A primeira legislação específica a tratar do tema do uso e tráfico de entorpecentes, retirando-o do âmbito do Código Penal, foi a Lei n ${ }^{\circ} 20.771$, de 1974, substituída posteriormente pela Lei $n^{\circ} 23.737$, em 1989.

A Lei n 20.771 sancionou com penas entre três e doze anos de prisão as atividades vinculadas ao tráfico e comercialização de estupefacientes, entre as quais o cultivo de plantas ou sementes, a produção, extração, fabricação ou preparação de estupefacientes, o seu comércio, distribuição, armazenamento ou transporte, assim como a sua entrega, facilitação ou aplicação em terceiros. A lei também previa penas de prisão de cinco a quinze anos para os financiadores e organizadores de qualquer das atividades antes descritas, e com três a oito anos de prisão, assim como a difusão pública do seu uso.

A lei previa ainda a aplicação de medida de segurança curativa, consistente em tratamento para desintoxicação e reabilitação, por tempo indeterminado, para o condenado pelos delitos acima com dependência física ou psíquica de estupefacientes, embora não tenham sido criadas as instituições previstas para a aplicação dessa medida.

A respeito da posse de estupefacientes para consumo pessoal, o art. $6^{\circ}$ da Lei n ${ }^{\circ} 20.771$ previa a pena de prisão de um a seis anos, mesmo que fossem destinados ao consumo pessoal. Isso significa que o tipo penal não repri- 
mia diretamente o consumo em si mesmo, mas sim indiretamente, punindo a posse da droga. Esta previsão legal entrou em choque com o dispositivo constitucional previsto no art. 19 da Constituição, que garantia a impunibilidade de ações privadas que não ofendessem a moral e a ordem pública, nem prejudicasse a terceiro.

Depois de uma longa polêmica jurisprudencial, em agosto de 1986 a Corte Suprema finalmente declarou a inconstitucionalidade da proibição penal da posse de estupefacientes para consumo pessoal (Virgolini, 1992:124), abrindo caminho para o reconhecimento da autonomia de consciência individual e convertendo-se em uma medida concreta de redução do âmbito de intervenção penal. A Corte Suprema fundamentou sua decisão pelo fato de que não havia investigações ou comprovações empíricas capazes de demonstrar que entre o consumo de estupefacientes e a periculosidade social do consumidor existisse uma vinculação necessária, que justificasse a penalização da posse de drogas. A Corte fez referência igualmente às recomendações de organismos internacionais que desaconselhavam a punição do consumidor, que na maioria dos casos se mostrou prejudicial para o tratamento ou reinserção social de quem mantinha uma relação ocasional com a droga (Cavallero, 1997:61-72).

Em sentido contrário à decisão da Corte Suprema, o debate prosseguiu, com a proliferação de posições no sentido de uma maior severidade no tratamento do consumo e tráfico de drogas no interior do campo político e nos meios de comunicação de massa.

O resultado foi a promulgação da Lei $\mathrm{n}^{\circ} 23.737$, em 1989, que não alterou substancialmente os tipos penais da lei anterior, mas trouxe um sensível aumento das penas cominadas. Embora tenha mantido a previsão de punição para a posse de estupefacientes para uso pessoal, a nova lei previu alternativas para a execução da pena de prisão, como a sua suspensão e substituição por medida de segurança curativa ou educativa.

$\mathrm{O}$ art. 11 desse diploma legal previu o aumento de um terço do máximo e da metade do mínimo de previsão de apenamento, nos seguintes casos:

“a) Si los hechos se cometieren en perjuicio de mujeres embarazadas o de personas disminuidas psíquicamente, o sirviéndose de menores de dieciocho años o en perjuicio de éstos;

b) Si los hechos se cometieron subrepticiamente o con violencia, intimidación o engaño;

c) Si en los hechos intervinieren tres o más personas organizadas para cometerlos; d) Si los hechos se cometieren por un funcionario público encargado de la prevención o persecución de los delitos aquí previstos o por funcionario público encargado de la guarda de presos y en perjuicio de éstos;

e) Cuando el delito se cometiere en las inmediaciones o en el interior de un establecimiento de enseñanza, centro asistencial, lugar de detención, institución deportiva, cultural o social o en sitios donde se realicen espectáculos o diversiones públicos o en otros lugares a los que escolares y estudiantes acudan para realizar actividades educativas, deportivas o sociales;

f) Si los hechos se cometieren por un docente, educador o empleado de establecimientos educacionales en general, abusando de sus funciones específicas."

Previu ainda a Lei ${ }^{\circ} 23.737$ a possibilidade de utilização de agentes policiais infiltrados, em seu art. 31 bis, conforme segue:

"Art. 31 bis. Durante el curso de una investigación y a los efectos de comprobar la comisión de algún delito previsto en esta ley o en el artículo 866 del Código Aduanero, de impedir su consumación, de lograr la individualización o detención de los autores, partícipes o encubridores, o para obtener y asegurar los medios de prueba necesarios, el juez por resolución fundada podrá disponer, si las finalidades de la investigación no pudieran ser logradas de otro modo, que agentes de las fuerzas de seguridad en actividad, actuando en forma encubierta:

a) Se introduzcan como integrantes de organizaciones delictivas que tengan entre sus fines la comisión de los delitos previstos en esta ley o en el artículo 866 del Código Aduanero, y;

b) Participen en la realización de alguno de los hechos previstos en esta ley o en el artículo 866 del Código Aduanero.

La designación deberá consignar el nombre verdadero del agente y la falsa identidad con la que actuará en el caso, y será reservada fuera de las actuaciones y con la debida seguridad.

La información que el agente encubierto vaya logrando, será puesta de inmediato en conocimiento del juez.

La designación de un agente encubierto deberá mantenerse en estricto secreto. Cuando fuere absolutamente imprescindible aportar como prueba la información personal del agente encubierto, éste declarará como testigo, sin perjuicio de adoptarse, en su caso, las medidas previstas en el artículo 31 quinques.”

Previu ainda o art. 31 ter. que não é punível o agente infiltrado que, como conseqüência necessária do desenvolvimento da atuação encomendada, tenha sido compe- 
lido a incorrer em delito, desde que a conduta não implique em pôr em perigo a vida ou a integridade física de uma pessoa ou a imposição de grave sofrimento físico ou moral a terceiro. Sendo acusado em um processo, o agente infiltrado fará saber ao juiz de instrução, de maneira confidencial, sua condição, e este deverá encerrar o processo sem revelar a verdadeira identidade do imputado.

$\mathrm{O}$ art. 31 quáter estabelece que "ningún agente de las fuerzas de seguridad podrá ser obligado a actuar como agente encubierto. La negativa a hacerlo no será tenida como antecedente desfavorable para ningún efecto".

Conforme o art. 31 quinques, estando com sua segurança ameaçada a pessoa que tenha atuado como agente infiltrado por haver sido descoberta sua verdadeira identidade, terá direito a optar entre permanecer na ativa ou aposentar-se, seja qual for o tempo que tenha trabalhado no serviço público, com proventos iguais aos que corresponderiam a quem tenha dois graus acima na carreira.

De acordo com o art. 31 sextes, o funcionário ou empregado público que revele indevidamente a real identidade de um agente infiltrado, assim como a nova identidade ou o domicílio de uma testemunha protegida, será reprimido com prisão de dois a seis anos, multa de 10.000 a 100.000 pesos e inabilitação absoluta perpétua para a função pública. Já o funcionário ou empregado público que, por imprudência, negligência ou inobservância dos deveres de seu cargo, permitir ou der ocasião a que outro conheça estas informações, será sancionado com prisão de um a quatro anos, multa de 1.000 a 30.000 pesos e inabilitação especial de três a dez anos para o cargo.

A Lei ${ }^{\circ} 25.241 / 00$ foi elaborada especificamente para o combate a fatos delitivos relacionados com o terrorismo. Para os efeitos desta lei, são considerados atos de terrorismo as ações delitivas cometidas por integrantes de associações ilícitas ou organizações constituídas com o fim de causar alarme ou temor, e que se realizem empregando substâncias explosivas, inflamáveis, armas ou quaisquer elementos de elevado poder ofensivo, colocando em perigo a vida ou a integridade de um número indeterminado de pessoas $\left(\operatorname{art} .1^{\circ}\right)$.

$\mathrm{O}$ art. $2^{\circ}$ deste diploma legal prevê a possibilidade de redução excepcional da pena, aplicando-se a da tentativa ou limitando-a à metade, ao imputado que, antes de ditada a sentença definitiva, colabore eficazmente com a investigação. Para obter o benefício, deverá ser fornecida informação essencial para evitar a consumação ou continuação do delito ou a perpetração de outro, ou que ajude a esclarecer o fato objeto da investigação ou outros conexos, ou que forneça dados de manifesta utilidade para comprovar a participação de outras pessoas no delito, desde que o delito em que esteja envolvido o beneficiário seja mais leve que aquele a respeito do qual forneça sua colaboração $\left(\operatorname{art} .2^{\circ}\right)$.

No mesmo sentido, o art. $3^{\circ}$ prevê a aplicação do mínimo legal de pena quando a informação fornecida permita comprovar a existência de associação ilícita, desbaratar suas atividades ou comprovar a intervenção de algum de seus membros no fato delitivo, determinando assim o submetimento a processo de quem não tenha sido imputado até então.

$\mathrm{O}$ art. $6^{\circ}$ prevê pena de prisão de um a três anos para qualquer das pessoas que, valendo-se das possibilidades abertas por esta lei, formulem afirmações falsas ou proporcionem dados inexatos sobre terceiros.

$\mathrm{O}$ art. $7^{\circ}$ trata da proteção ao imputado que tenha optado por colaborar, passando a correr riscos à sua integridade pessoal e à de sua família, mediante provisão de recursos indispensáveis para a mudança de suas atividades laborais e substituição de identidade.

\section{INFORMALIZAÇÃO OU SIMPLIFICAÇÃO DO PROCESSO PENAL}

Em que pese a existência de modelos diferenciados, os elementos conceituais que configuram um tipo ideal de informalização da justiça nos Estados contemporâneos são os seguintes: uma estrutura menos burocrática e relativamente mais próxima do meio social em que atua; aposta na capacidade dos disputantes promover sua própria defesa, com uma diminuição da ênfase no uso de profissionais e da linguagem legal formal; preferência por normas substantivas e procedimentais mais flexíveis, particularistas, ad hoc; mediação e conciliação entre as partes mais do que adjudicação de culpa; participação de não juristas como mediadores; preocupação com uma grande variedade de assuntos e evidências, rompendo com a máxima de que "o que não está no processo não está no mundo"; facilitação do acesso aos serviços judiciais para pessoas com recursos limitados para assegurar auxílio legal profissional; um ambiente mais humano e cuidadoso, com uma justiça resolutiva rápida, e ênfase em uma maior imparcialidade, durabilidade e mútua concordância no resultado; geração de um senso de comunidade e estabelecimento de um controle local através da resolução judicial de conflitos; maior relevância em sanções não coercitivas para obter acatamento (Azevedo, 2000a:108).

No Brasil, a incorporação dessas inovações no sistema judicial teve impulso a partir do final dos anos 80, em 
especial após a promulgação da Constituição de 1988. Uma série de novos mecanismos para a solução de litígios foi prevista, com vistas à agilização dos trâmites processuais, entre os quais têm um significado relevante os Juizados Especiais Cíveis e Criminais, voltados para as chamadas pequenas causas e para os delitos de menor potencial ofensivo, regulamentados pela Lei Federal n ${ }^{\circ} 9.099$, de setembro de 1995.

A implantação dos Juizados Especiais Criminais - JEC integra uma lógica de informalização, entendida não como a renúncia do Estado ao controle de condutas e ao alargamento das margens de tolerância, mas como a procura de alternativas de controle mais eficazes e menos onerosas (Dias e Andrade, 1992:403). Para os Juizados Especiais Criminais vão confluir determinados tipos de delitos (com pena máxima em abstrato até um ano), e de acusados (não reincidentes). Com a sua implantação, esperava-se que as antigas varas criminais pudessem atuar com maior prioridade sobre os chamados crimes de maior potencial ofensivo (Azevedo, 2000a; 2000b; 2001; 2002).

De acordo com o que estabeleceu o legislador no art. 62 da Lei $n^{\circ} 9.099 / 95$, o processo perante os Juizados Especiais Criminais deve ser orientado pelos critérios da oralidade, informalidade, economia processual e celeridade, objetivando, sempre que possível, a reparação dos danos sofridos pela vítima e a aplicação de pena não privativa de liberdade. Dispensando a realização do inquérito policial, a Lei $\mathrm{n}^{\circ}$ 9.099/95 determina que a autoridade policial, ao tomar conhecimento do fato delituoso, deve imediatamente lavrar um termo circunstanciado do ocorrido e encaminhálo ao Juizado, se possível com o autor do fato e a vítima, providenciando a requisição dos exames periciais necessários para a comprovação da materialidade do fato (art. 69). Não sendo possível o comparecimento imediato de qualquer dos envolvidos ao Juizado, a Secretaria do Juizado deverá providenciar a intimação da vítima e do autor do fato, por correspondência com aviso de recebimento, para que compareçam à audiência preliminar (art. 71).

$\mathrm{Na}$ audiência preliminar, presentes o representante do Ministério Público, o autor do fato e a vítima, acompanhados de advogado, o juiz esclarecerá sobre a possibilidade de composição dos danos, assim como sobre as conseqüências da aceitação da proposta de aplicação imediata de pena não privativa de liberdade ao autor do fato (art. 72). Nos crimes de ação penal privada e de ação penal pública condicionada à representação, o acordo para composição dos danos extingue a punibilidade. Não obtido o acordo, o juiz dá imediatamente à vítima a oportunidade de exercer o direito de oferecer queixa-crime ou representação verbal (art. 75).
Havendo queixa-crime ou representação ou sendo o crime de ação penal pública incondicionada, o Ministério Público poderá propor ao autor do fato a transação penal, com a aplicação imediata de pena restritiva de direitos ou multa, a não ser no caso do acusado ser reincidente, ou no caso de "não indicarem os antecedentes, a conduta social e a personalidade do agente, bem como os motivos e as circunstâncias, ser necessária e suficiente a adoção da medida" (art. 76). Não aceita a proposta, o representante do Ministério Público oferecerá ao juiz, de imediato, denúncia oral, e o processo seguirá o rito sumaríssimo, previsto na Lei ${ }^{\circ}$ 9.099/95.

Oferecida a denúncia, poderá ainda o representante do Ministério Público propor a suspensão do processo por dois a quatro anos, desde que o agora denunciado não esteja sendo processado ou não tenha sido condenado por outro crime. A suspensão será revogada se, no curso do prazo, o denunciado for processado por outro crime ou descumprir qualquer outra condição imposta. Expirado o prazo sem revogação, o juiz declarará extinta a punibilidade. Caso não seja possível a suspensão do processo, o juiz deverá intimar as partes para a audiência de instrução e julgamento, que se inicia com a resposta oral da defesa à acusação formulada na denúncia ou queixa-crime. Aceita a argumentação da defesa, o juiz não recebe a denúncia ou queixa e encerra o processo. Recebida a denúncia ou queixa, são ouvidas a vítima e as testemunhas de acusação e de defesa, o acusado é interrogado e realizam-se os debates orais entre defesa e acusação. Em seguida, o juiz profere a sentença final condenatória ou absolutória.

Os recursos previstos pela Lei no $9.099 / 95$ são a apelação (em caso de sentença condenatória ou absolutória ou da decisão de rejeição da denúncia ou queixa) e os embargos de declaração (em caso de obscuridade, contradição, omissão ou dúvida na sentença), a serem encaminhados a uma Turma Recursal composta de três juízes em exercício no primeiro grau de jurisdição.

$\mathrm{Na}$ Argentina, a informalização ou simplificação dos procedimentos penais foi adotada mediante a Lei $\mathrm{n}^{\circ} 24.825 /$ 99, que incorporou ao Título II do Livro III do Código Procesal Penal de la Nación o Capítulo IV, art. 431 bis, tratando do chamado juízo abreviado.

Tecnicamente, não se trata da criação de uma nova instância judicial, e sim de um procedimento abreviado de conclusão da causa, visando a aceleração do processo penal comum. Para Luis Niño (apud Alvero e Ranuschio, 2001:1), "en lugar de abreviar la etapa del procedimiento preparatorio, clara supervivencia inquisitiva en cuerpos 
de leyes como el vigente en nuestra órbita federal, suprime el juicio, que es la etapa republicana por excelencia".

O fundamento da instauração do mecanismo procedimental do Juízo Abreviado é a impossibilidade do sistema judicial penal para dar conta da grande quantidade de casos em tramitação. Diante da impossibilidade de julgar todos os delitos que chegam até o Judiciário, e do fato de que a solução prática era a prescrição, optou-se por substituir o princípio da verdade real pelo da verdade consensuada, já que a aplicação de uma pena passa a depender de um acordo entre o acusado e o Ministério Fiscal.

Segundo o inciso $1^{\circ}$ da referida Lei, se o Ministério Fiscal estimar suficiente a imposição de uma pena privativa de liberdade inferior a seis anos ou uma pena não privativa de liberdade, poderá solicitar, ao formular o requerimento para a elevação a juízo, que se proceda de acordo com o chamado Juízo Abreviado. Neste caso, deverá colocar expressamente o pedido de pena acordado com o acusado.

O Juízo Abreviado não é aplicável para os delitos de ação privada, mas somente para os casos de pena de reclusão, inabilitação e multa ou penas conjuntas.

A Lei estabelece dois momentos nos quais se pode realizar o pedido de Juízo Abreviado: no momento de elevação a juízo, que implica uma negociação e um acordo prévio entre o acusado e o representante do Ministério Fiscal; ou no momento dos atos preliminares no Tribunal Oral, até o momento da fixação da data da audiência de debate. Embora a Lei nada diga a respeito, no caso de que o acordo se efetue no Tribunal Oral quem irá realizar a negociação da pena será o Fiscal General, que é quem irá atuar perante o Tribunal Oral (Alvero e Ranuschio, 2001:2).

$\mathrm{O}$ inciso $2^{\circ}$ da Lei estabelece que, para que a solicitação de Juízo Abreviado seja admissível, deverá estar acompanhada da manifestação de conformidade do imputado, assistido por defensor, sobre a existência do fato e sobre a participação nele, descritas no requerimento de elevação a juízo e da qualificação legal respectiva. A conformidade sobre a existência do fato e sua participação, conforme formulada pela acusação fiscal, e sobre a qualificação do delito, não implica uma confissão. Se não se admite o Juízo Abreviado o procedimento seguirá conforme o procedimento comum, e a conformidade não implicará um indício contrário ao imputado.

$\mathrm{O}$ inciso $3^{\circ}$ da Lei estabelece que o Juiz de Instrução encaminhará a solicitação e a manifestação de conformi- dade ao Tribunal de Juicio Oral. O pedido poderá ser negado com base na necessidade de um melhor conhecimento dos fatos; na discrepância fundada com a qualificação legal; em que o pedido tenha sido feito extemporaneamente; em que a conformidade do imputado tenha sido condicionada ou afetada por algum vício de vontade ou não resulte congruente com o conteúdo da prova produzida na instrução; ou em que sejam vários os imputados e não haja concordância de todos eles.

Conforme o inciso $4^{\circ}$ se o Tribunal rechaça o acordo de juízo abreviado, deve-se proceder segundo as regras do procedimento comum, remetendo-se a causa à instância devida. Neste caso, a conformidade prestada pelo imputado não será tomada como indício contra ele, nem o pedido penal formulado vincula o representante do Ministério Fiscal que atua no debate.

$\mathrm{O}$ inciso $5^{\circ}$ dispõe que a sentença que homologa o acordo de juízo abreviado deverá fundar-se nas provas recebidas durante a instrução, não podendo ser imposta uma pena superior ou mais grave que a pedida pelo Ministério Fiscal. Os requisitos da sentença são idênticos, portanto, àqueles que seriam exigidos uma vez realizados os debates. Não pode basear-se somente no acordo. Caso o Tribunal decida aplicar uma pena menor, a única exigência é que seja respeitado o mínimo apenamento legal estabelecido no tipo penal respectivo.

Alvero e Ranuschio (2001:5) afirmam: "El problema se plantea si el Tribunal, de acuerdo al principio de culpabilidad y al momento de la graduación de la pena, decide que debería imponer una pena superior (esto no está previsto como causa de rechazo del acuerdo como lo hizo la Provincia del Chaco). Al imponerle el Fiscal al Juez la pena máxima aplicável, estaría ejerciendo atribuciones judiciales. Al selecionar la pena, imposibilita al juez ejercer integramente su función jurisdiccional que entre otras cosas supone la facultad de graduar las sanciones que impone. En este caso, se comiezan a confundir los roles de los órganos estatales que en el mundo del derecho moderno están muy bien delimitados y demarcados".

O inciso $6^{\circ}$ estabelece que contra a sentença é admissível o recurso de cassação, podendo este ser interposto pelo Fiscal ou pelo querelante contra a sentença que aplica uma pena inferior à acordada ou absolve o imputado. O imputado não terá direito a recorrer do acordo por ele firmado, por ausência de interesse jurídico, salvo no caso de invocação de alguma causa de nulidade.

Segundo o inciso $7^{\circ}$, a ação civil ex delito não será resolvida pelo juízo abreviado, salvo se existir acordo entre 
as partes neste sentido. O querelante não tem direito a ser escutado antes da decisão, tampouco se prevê a possibilidade de audiência com a participação do imputado e do querelante para a obtenção de um acordo. Não obstante, tem o querelante a possibilidade de recorrer da sentença, mediante recurso de cassação, na medida em que a sentença possa influir sobre o resultado de uma ação civil posterior.

Para seus críticos, o sistema de juízo abreviado é inconstitucional, uma vez que, sob a aparência de um sistema acusatório, tem-se na verdade uma fórmula com alto conteúdo inquisitivo, utilizando-se de uma verdadeira coação sobre o acusado, a quem se coloca frente ao dilema de aceitar o trâmite acelerado ou confrontar-se com o risco de uma condenação maior, se optar pelo juízo comum. Para Schunemann (apud Alvero e Ranuschio, 2001: 9) "no se garantiza el consenso, sino sólo un compromiso al cual la parte más débil debe adherirse, por necesidad, al punto de vista de la parte más fuerte, además en tales casos no es posible individualizar la pena".

Além disso, o juízo abreviado reuniria a faculdade acusatória e, em certa medida, a decisória sobre a existência do fato punível e a decisória sobre o tipo e tamanho da pena, faculdade que, quando o caso vai ao juízo comum, estariam repartidas entre o Ministério Fiscal e o Juiz.

\section{GLOBALIZAÇÃO, PÓS-MODERNIDADE E POLÍTICA CRIMINAL}

O fenômeno da globalização trouxe para o âmbito do controle penal uma série de transformações na forma de regulação legal erigida na modernidade. Diante da insegurança gerada pelo processo de globalização, nota-se um aumento na sua utilização, tanto simbólica quanto instrumental. No entanto, como alertam Luiz Flávio Gomes e Alice Bianchini (2002:19), é preciso distinguir as tendências político-criminais na era da globalização das transformações no âmbito da legislação penal.

Segundo estes autores, as principais tendências de política criminal no contexto contemporâneo seriam a descriminalização dos chamados crimes antiglobalização (descaminho, evasão de divisas, etc.); globalização da política criminal, especialmente no que tange à criminalidade transnacional; globalização da cooperação policial e judicial, mediante tratados ou acordos de cooperação bilaterais ou multilaterais; globalização da justiça criminal, com a criação do Tribunal Penal Internacional pelo Tratado de Roma (Gomes; Bianchini, 2002:19-22).
Já no que diz respeito às transformações do direito penal, a globalização traria as seguintes conseqüências: a globalização dos crimes e dos criminosos, em razão das facilidades da globalização - livre circulação financeira, informatização - fazendo com que os crimes se globalizem (narcotráfico, tráfico de armas, de órgãos humanos, corrupção internacional); a globalização dos bens jurídicos, traduzindo a idéia da sociedade de risco, como a ecologia, genética, segurança nas comunicações; a globalização das vítimas, no sentido de que da vítima individual passou-se a ter a vítima coletiva, e, em alguns casos, a vítima planetária (como nos casos de delitos ambientais, vírus na informática, etc.); a globalização da explosão carcerária; a globalização da desformalização da justiça penal, reduzindo garantias penais e processuais, para que o sistema seja mais eficiente; a hipertrofia do Direito Penal, pela inflação legislativa (Gomes; Bianchini, 2002:22-26).

A "distorcionante" instrumentalização do direito penal (Gomes; Bianchini, 2002) está vinculada a vários fatores, podendo destacar-se, entre eles, as influências políticas e da mídia. Dadas as condições da realidade social, o Estado contemporâneo, que reduz a intervenção em matéria social, endurece a legislação penal, transformando o direito penal de forma de intervenção subsidiária em principal forma de combate aos problemas sociais. Analisando aspectos da política criminal nas sociedades pós-industriais, o criminólogo espanhol Jesus-María Silva Sanchez constata a existência de uma tendência dominante na grande maioria dos países no sentido da introdução de novos tipos penais, assim como um agravamento das penas para os já existentes, fato que o leva a caracterizar o momento atual como de expansão do direito penal (Silva Sánchez, 2002:21).

Rejeitando uma explicação simplista para este fato, como a daqueles que afirmam que o mesmo se deve à perversidade dos gestores do aparato estatal e dos legisladores, na busca permanente de uma solução fácil e simbólica aos problemas sociais mediante a legislação penal, Silva Sánchez reconhece que a questão é mais complexa, e, na linha de David Garland (2001), procura relacionar o fenômeno com causas mais profundas e múltiplas, que têm suas raízes no modelo social que vem se configurando no decorrer das últimas décadas.

Por um lado, há que reconhecer a existência de uma verdadeira demanda social por mais proteção frente ao incremento da criminalidade, canalizada de modo mais ou menos irracional como demanda de punição. Para Silva Sánchez, "a profundidade e a extensão das bases sociais 
da atual tendência expansiva do direito penal não têm nada a ver com as que na década de 70 - e posteriores - respaldavam o movimento, inicialmente norte-americano, de law and order" (Silva Sánchez, 2002:224). Naquele momento, enquanto alguns setores apoiavam propostas de reação legal, judicial e policial mais contundentes contra a criminalidade urbana violenta, outros - os excluídos, os intelectuais e os movimentos de direitos humanos - opunham-se a elas. A atual tendência expansiva, ao contrário, mostra uma ampla unanimidade, um consenso quase geral, sobre as virtudes do direito penal como instrumento de proteção dos cidadãos.

A partir desta matriz explicativa, é possível compreender a complexidade do processo de transformação do controle penal nas sociedades contemporâneas, em que convivem mudanças no sentido de um abrandamento dos mecanismos de controle, especialmente por mecanismos terapêuticos ou compensatórios, com a tendência a optar pela alternativa repressiva ou carcerária para a tutela de um número cada vez maior de interesses e para a solução de conflitos sociais.

O resultado de todo este conjunto de mudanças no âmbito do controle penal ainda não está de todo claro, e é muitas vezes paradoxal e ambíguo. De um lado, não se pode negar uma ampliação das possibilidades de controle por parte do Estado. De outro, a complexidade do contexto social em que operam os mecanismos de controle, e as dificuldades de gerenciamento do próprio aparato punitivo, são de tal ordem que cada vez mais se torna fictícia a idéia de um monopólio dos meios de violência legítima por parte do mesmo, assim como se reforçam as características de seletividade do sistema e a impunidade para a maioria dos delitos.

\section{REFERÊNCIAS BIBLIOGRÁFICAS}

ADORNO, S. Violência, controle social e cidadania: dilemas da administração da Justiça Criminal no Brasil. Revista Crítica de Ciências Sociais, n.41, p.101-127, dez. 1994.

ALVERO, M.; RANUSCHIO, D. El Juicio Abreviado en el Proceso Penal. Disponível em: <http://www.pjn.gov.ar/criminac/TO21/ juicio abreviado en el proceso p.htm>. Acesso em: 29 jul. 2001.

ARGENTINA. Código Penal de la Nación Argentina. 37. ed. Buenos Aires: Abeledo Perrot, 2002a.

. Código Procesal Penal de la Nación. 9. ed. Buenos Aires: Abeledo Perrot, 2002b. na, 2001

Régimen Penal Argentina. Buenos Aires: Legis Argenti-

Rodrigo Ghiringhelli de Azevedo: Professor e Pesquisador do Programa de Pós-Graduação em Sociologia/UFRGS(rgdeazevedo@uol.com.br).
Código Penal y Leyes Complementarias. Buenos Aires: Editorial Estudio, 1999.

AZEVEDO, R.G. Conciliar ou Punir? - Dilemas do controle penal na época contemporânea. In: WUNDERLICH, A. et al. Diálogos sobre a justiça dialogal. Rio de Janeiro: Lumen Juris, 2002. p.5580 .

Juizados Especiais Criminais: uma abordagem sociológica sobre a informalização da justiça penal no Brasil. Revista Brasileira de Ciências Sociais, v.16, n.47, p.97-110, 2001.

Informalização da Justiça e Controle Social. São Paulo: IBCCrim, 2000a.

A informalização da justiça penal e a Lei n ${ }^{\circ}$ 9.099/95 Entre a rotinização do controle social e a ampliação do acesso à justiça. Revista Brasileira de Ciências Criminais, ano 8, n.31, p.311-324, 2000b.

BARATTA, A. Funções Instrumentais e Simbólicas do Direito Penal. Revista Brasileira de Ciências Criminais, n.5, p.5-24, jan./mar. 1994.

BRASIL. Constituição da República Federativa do Brasil. Rio de Janeiro: Forense, 2002.

. Constituição Federal, Código Penal, Código de Processo Penal. Organização de Luiz Flávio Gomes. São Paulo: Ed. Revista dos Tribunais, 1999.

CAVAllero, R.J. Justicia Criminal - Debates en la Corte Suprema. Buenos Aires: Universidad, 1997.

CHOUKR, F.H. Processo Penal de Emergência. Rio de Janeiro: Lumen Juris, 2002.

DIAS, J. de F.; ANDRADE, M.C. Criminologia - o homem delinqüente e a sociedade criminógena. Coimbra: Coimbra Ed., 1992.

FERRAJOLI, L. Direito e razão: teoria do garantismo penal. São Paulo: Ed. Revista dos Tribunais, 2002.

GARLAND, D. The Culture of Control - Crime and Social Order in Contemporary Society. Oxford: Oxford University Press, 2001.

GOMES, L.F.; BIANCHINI, A. O Direito Penal na Era da Globalização. São Paulo: Ed. Revista dos Tribunais, 2002.

KOERNER, A. Desordem Legislativa, Distribuição de Poder e Desigualdade Social - Reflexões a Propósito da Lei no 9.677. Disponível em: <http://www.ibccrim.com.br/desordem.htm>. Acesso em: 15 fev. 2000.

SANTOS, B. de S. Uma cartografia simbólica das representações sociais: Prolegómenos a uma concepção Pós-Moderna do Direito. Revista Brasileira de Ciências Criminais, ano 4, n.13, p.253277, 1996.

SILVA SÁNCHEZ, J.-M. A expansão do Direito Penal - Aspectos da política criminal nas sociedades pós-industriais. Tradução de Luiz Otavio de Oliveira Rocha. São Paulo: Ed. Revista dos Tribunais, 2002.

VELHO, G.; ALVITO, M. (Orgs.). Cidadania e violência. Rio de Janeiro: UFRJ e FGV, 1996.

VIRGOLINI, J. El Control Social y su Articulación con el Sistema Penal. In: ZAFFARONI, E.R. et al. El Sistema Penal Argentino. Buenos Aires: AdHoc, 1992. p.75-164.

ZAFFARONI, E.R. Em busca das penas perdidas. Rio de Janeiro: Revan, 1991. 